\title{
Investigation of the phytohormonal and antioxidant enzymatic changes caused by Pyrenophora teres $\mathrm{f}$. teres infection in barley
}

\author{
Viola KUNOS ${ }^{1}$ - Mónika CSÉPLŐ ${ }^{2}$ - Magda PÁL ${ }^{3}$ - József BAKONYI ${ }^{4}$ - \\ Klára MÉSZÁROS 5
}
1: Agricultural Institute, Centre for Agricultural Research, Hungarian Academy of Sciences, Martonvásár, Hungary,kunos.viola@agrar.mta.hu-cseplo.monika@agrar.mta.hu-pal.magda@agrar.mta.hu-meszaros. klara@agrar.mta.hu
2: Plant Protection Institute, Centre for Agricultural Research, Hungarian Academy of Sciences, Budapest, Hungary, bakonyi.jozsef@agrar.mta.hu

Keywords: Pyrenophora teres f. teres, Hordeum vulgare, antioxidant activity, phytohormones, biotic stress

\section{Introduction}

In terms of the crop yield and sowing area, barley (Hordeum vulgare L.) is one of the most important cereals in the world. In addition to the human nutritional value of barley, it is an important animal feed and component of the brewing industry.

Pyrenophora teres f. teres (PTT), the causal agent of the net form of net blotch disease, is one of the most important pathogens of barley. The effectiveness of the resistance against the fungus is influenced by the developmental stage of the plant and the pathotype of the pathogen.

Phytohormones and antioxidant enzymes have an important role in the activation of plant defence mechanisms. The reactive oxygen species (ROS) are produced during the initial oxidative burst as part of the gene-for-gene resistance reaction (Liu et al., 2011). Plants have got a defence system to remove ROS by enzymatic and non-enzymatic mechanisms. Ascorbate-peroxidase (APX) and guaiacol-peroxidase (GPX) enzymes are important in the control of pathogens (Asthir et al., 2010). Elucidation of the causal relation between ROS is further complicated by the fact, that phytohormones, such as salicylic acid (SA) and jasmonic acid (JA) also influence the elicitation and expression of HR (Torres et al., 2005). The function of phytohormones and enzymes during the pathogenesis is still unclear.

The aim of this study was to examine the changes in the SA/JA hormone system and antioxidant enzymes caused by $P$. teres f. teres infection in barley.

\section{Materials and methods}

To investigate the seedling resistance, 260 genotypes from our barley variety collection were tested under greenhouse conditions. The plants were inoculated at two-leaf stage with conidia (10.000 conidia/ml) of monosporic P. teres f. teres isolates (H-618 and H-774). The type of symptoms were evaluated on the second leaf four times from the appearance of the first lesion to total infection of sensitive genotypes using the Tekauz scale (Tekauz, 1985), and the area under disease progression curves (AUDPC) were calculated.

For the examination of hormone system and antioxidant enzymes samples were taken at $0^{\text {th }}, 1^{\text {st }}, 2^{\text {nd }}, 3^{\text {rd }}$, and $15^{\text {th }}$ days after inoculation. The extraction and quantification of SA/ JA and the measurement of antioxidant enzyme activity were performed as described by Pál et al. (2013). 


\section{Results and discussion}

Based on the AUDPC values, six barley genotypes were selected to investigate the role of antioxidant enzymes and the SA/JA hormone system. The PTT infection caused significant change in both of the hormones and the antioxidant enzymes system $(p=0,01)$. The variation of it was dependent on isolates and varieties. The concentration of salicylic acid was the highest in the susceptible varieties (BC5, BC52) and the lowest in the most resistant $\mathrm{BC6}$ variety. In contrast, the concentrations of JA were higher in the resistant genotype (BC6) and lower in susceptible ones (BC5, BC52). The activity of APX enzyme decreased in all varieties in the case of isolate H-618, whereas we could not observe this tendency in the case of isolate H-774. The GPX enzyme activity increased as the result of the infection with isolate $\mathrm{H}-774$, except for cultivar $\mathrm{BC} 52$, and. reached the maximum value at the $15^{\text {th }}$ days after inoculation. Significant correlations were detected between the activity of APX, GPX enzymes and SA, JA hormone concentrations, which confirm the relationship between the two systems. Some impact of SA/JA and antioxidant enzymes on plant disease severity was observed, but it was under the statistically significant level.

\section{Conclusions}

In this study, the effect of $P$. teres f. teres infection on antioxidant enzymatic and hormonal systems were investigated. The results could not identify clearly the connection between the disease severity and the changes in the phytohormones and antioxidant enzymes, therefore further experiments are necessary to study the role of ascorbate-peroxidase, guaiacol-peroxidase and salicylic acid/jasmonic acid hormone system in the plant defence mechanisms.

\section{Acknowledgement}

This study was financed by NKFI 119276, TÉT_15-1-2016-0113 and GINOP-2.3.3-15-2016-00029.

\section{References}

Asthir, B., Kounda, A., Bains, N. S., Mann, S. K. (2010): Stimulation of antioxidative enzymes and polyamines during stripe rust disease of wheat. Biol. Plantarum, 54, 329-333. DOI: 10.1007/s10535-010-0057-4

Liu, Z., Ellwood, S. R., Oliver, R. P., Friesen, T. L. (2011): Pyrenophora teres: profile of an increasingly damaging barley pathogen. Mol. Plant Pathol. 12 (1), 1-19. DOI: 10.1111/j.1364-3703.2010.00649.x.

Pál, M., Kovács, V., Vida Gy., Szalai, G., Janda, T. (2013): Changes induced by powdery mildew in the salicylic acid and polyamine contents and the antioxidant enzyme activities of wheat lines. Eur. J. Plant Pathol., 135, 35-47. DOI: 10.1007/s10658-012-0063-9

Robert-Seilaniantz, A., Navarro, L., Bari, R.., Jones, J. D. G. (2007): Pathological hormone imbalances. Curr. Opin. Plant Biol., 10, 372- 379. DOI: 10.1016/j.pbi.2007.06.003

Steffenson, B. J., Hayes, P. M., Kleinhofs, A. (1996): Genetics of seedling and adult plant resistance to net blotch (Pyrenophora teres f. teres) and spot blotch (Cochliobolus sativus) in barley. Theor. Appl. Genet., 92 , 552-558. DOI: 10.1007/BF00224557

Tekauz, A. (1985): A numerical scale to classify reactions of barley to Pyrenophora teres. Can. J. Plant Pathol., 7, 181-183. DOI: 10.1080/07060668509501499

Torres, M. A., Jones, J. D., Dangl, J. L. (2005): Pathogen-induced, NADPH oxidase-derived reactive oxygen intermediates suppress spread of cell death in Arabidopsis thaliana. Nat Genet. 37(10), 1130-1134. DOI: $10.1038 / \mathrm{ng} 1639$ 